\title{
POLISH TEXTILE AND APPAREL INDUSTRY: GLOBAL SUPPLY CHAIN MANAGEMENT PERSPECTIVE
}

\author{
Adam Sadowski', Bogusława Dobrowolska², Beata Skowron-Grabowska ${ }^{3}$, Andrzej Bujak ${ }^{4}$ \\ 1 Institute of Logistics and Informatics, University of Lodz, 90-214 Lodz, 37 Rewolucji 1905r. Street, Lodz, Poland+ \\ 2 Department of Economic and Social Statistics, University of Lodz, 90-214 Lodz, 37 Rewolucji 1905r. Street, Lodz, Poland \\ 3 Department of Enterprise Management, Czestochowa University of Technology, Management Faculty, 19b Armii Krajowej Street, 4 \\ 2-200 Czestochowa, Poland \\ 4 WSB University in Wroclaw, Fabryczna Street 29-31, 53-609 Wrockaw, Poland \\ *Corresponding author. E-mail: adam.sadowski@uni.lodz.pl (Adam Sadowski); boguslawa.dobrowolska@uni.lodz.pl (Bogusława Dobrowolska); \\ beata.skowron-grabowska@wz.pcz.pl (Beata Skowron-Grabowska); andrzej.bujak@wsb.wroclaw.pl (Andrzej Bujak)
}

\begin{abstract}
:
The article presents changes that took place in the textile and apparel (T\&A) industry in Poland in the years 20042020. To describe the changes, we adopted the supply chain management perspective, which allowed for a global view of the changes taking place. We discuss the basic characteristics, such as the size and structure of the industry, innovation, production value, and the use of information and communications technology (ICT). In the research, we used the databases of the Central Statistical Office (GUS) on the sold production of the T\&A industry, as well as imports and exports. Our research shows that, at the level of basic characteristics, the industry is close to the European model. However, it is characterized by a smaller share of small companies in the structure of enterprises. The research showed an upward trend in the production of sold textiles and, to a lesser extent, apparel. At the same time, the operation of the Polish T\&A industry is influenced by the import of finished products and raw materials from China, Germany, Bangladesh, and Turkey. The export is directed to the German, Czech, Romanian, and Ukrainian markets. The article provides an overview of the development trends in the Polish T\&A industry in the broad context of international conditions.
\end{abstract}

\section{Keywords:}

Polish textile and apparel industry, production, trade, global supply chain

\section{Introduction}

The textile industry is classified as a low-technology industry, which affects its specificity and strong dependence on both the raw material base and the markets for finished products. This leads to the creation of complex structures for the flows of materials and finished products of the textile industry with a global scope. This also applies to the Polish textile industry, which is a complex system sensitive to changes in both the supply and the outlet markets for finished products [1]. Household expenditure on clothing is steadily increasing and places Poland in the seventh place in the European Union (EU) [2]. The way in which household members purchase clothes is also changing. Poland, along with Russia, the United States (US), Spain, France, the United Kingdom, Israel, Korea, and the Middle East, is one of the most important markets for Ali Express in the sale of clothing [3].

Showing these dependencies requires looking at the production of the textile industry in Poland from the perspective of supply chain management. The demand-oriented nature of creating global supply chain processes requires an analysis of imports, exports, and production in the textile industry.
The aim of this article is to analyze the changes taking place in the sold industrial production, imports, and exports of the textile and apparel (T\&A) industry in Poland in the context of trends in the global supply chain of the textile industry. These changes are due to global trends in the transformation of supply chain management in T\&A enterprises. They are related to main supply chain processes, such as planning, sourcing, production, and delivery to customers within retail sales networks. The drive for sustainable operations and sustainable supply chain management in the T\&A industry has resulted, as across entire Europe, in changing the location of supply chain processes and moving sourcing and production processes to countries with lower environmental standards and lower labor costs.

The research used the following statistical methods: structure, correlation, regression, and dynamics analysis. Calculations were made in the PS Imago software on the basis of data describing the textile industry in Poland. The time scope of the research on changes in production covered the years 20102018. On the other hand, the trends of changes in imports and exports covered the years 2004-2020. The research used databases and publications of the Central Statistical Office (Główny Urząd Statystyczny or GUS) in Warsaw. 


\section{Key parameters of the T\&A industry in Poland}

The production of the textile industry in Poland is shaped, similarly to that in the EU countries, by international relations related to the flow of raw materials for the production of finished products, as well as production of textile products and apparel. These relations result from international agreements on trade and commercial exchange of goods, according to which the EU market is treated primarily as an outlet for the finished products of the textile industry. In Poland, in 2018, in the structure of sold production of industrial products, the production of textiles and apparel accounted for $1.0 \%$ and $0.4 \%$, respectively [Statistical Yearbook of Industry; Central Statistical Office 2019]. In the period 2005-2018, there were two opposing trends in the textile industry in Poland. The first one was the developmental trend in the production of textile products, which is confirmed by the 68.7 increase in the number of entities producing textile products. The second, degressive trend in the production of clothing resulted in a decrease in the number of active entities by $65.0 \%$. The Herfindahl-Hirschman Index and the Lorenz factor of production concentration sold in 2018 are higher for the production of textile products and amount to 0.035 and 0.736 , respectively. For the production of apparel, they are lower and amount to 0.004 and 0.579 , respectively, which proves a stronger competitive position of enterprises involved in the production of textiles in Poland. In the production of textiles, $19.9 \%$ of entities have an $80 \%$ share in the value of sold production and $39.8 \%$ in the production of apparel. The structure of the Polish textile industry is close to the EU average. Enterprises employing $<10$ people account for approximately $70 \%$ of all entities involved in the production of textiles and apparel [Statistical Yearbook of Industry; Central Statistical Office 2019]. In the EU, enterprises with 0-9 employees account for $88.8 \%$ of the total, and $99.8 \%$ of all enterprises are micro-, small-, and medium-sized enterprises [4]. Further, $31 \%$ of enterprises in the textile industry in Poland produce textiles and $69 \%$ of companies are involved in the production of apparel. The structure of the industry in the EU is very similar to that in Poland, with the shares being respectively $33 \%$ and $67 \%$. The number of economic entities in the textile industry in Poland is $>19,000$ enterprises (Table 1 ). Almost all of them belong to the private sector. Productivity in the textile industry differs significantly depending on the type of activity (Table 2). It is the largest for enterprises involved in the preparation and spinning of textile fibers and amounts to PLN 385,800. The productivity is the lowest for enterprises that manufacture wearing apparel, except fur apparel, and amounts to PLN 115,700. For comparison, the average productivity for the textile industry in the EU in 2018 was EUR 30,200 . As the research conducted in the Italian T\&A industry shows, an enterprise's economic results and productivity directly affect the way of financing the activity, which is associated with the risk of implementing innovations [5]. Other studies - carried out in the Spanish T\&A industry - prove that a large expenditure on research and development (R\&D) does not necessarily translate into the development of innovation. For example, specialization, formalization, management attitude, and internal communication are of key importance for innovation [6].

The research conducted by the Central Statistical Office (GUS) on the group of medium-sized and large enterprises showed significant differences in product and process innovation in the textile industry (Table 3 ). It can be observed that the size of the enterprise influences the introduction of innovations. Most innovations are introduced in the area of textile production in large enterprises, i.e., $66.7 \%$. At the same time, the level of innovation is greater in enterprises involved in the production of textiles compared to those involved in the production of apparel. Moreover, the percentage share of enterprises that introduced product innovations in the field of textile production is more than twice as high as that of enterprises involved in the production of apparel (Figure 1). This shows the main area of R\&D in the textile industry in Poland. Smaller differences occur in the share of enterprises that have introduced new or significantly improved business processes $(29.2 \%$ and $18.9 \%$, respectively). The innovativeness of enterprises in the textile industry is also influenced by the use and development of information and communications technology (ICT) in their contacts with customers (Table 4). Considering traditional forms and tools of communication, such as the Internet, websites, and e-government, a large number of enterprises use these modes, whereas, as far as modern technologies are concerned, the textile industry does not use cloud computing or social media.

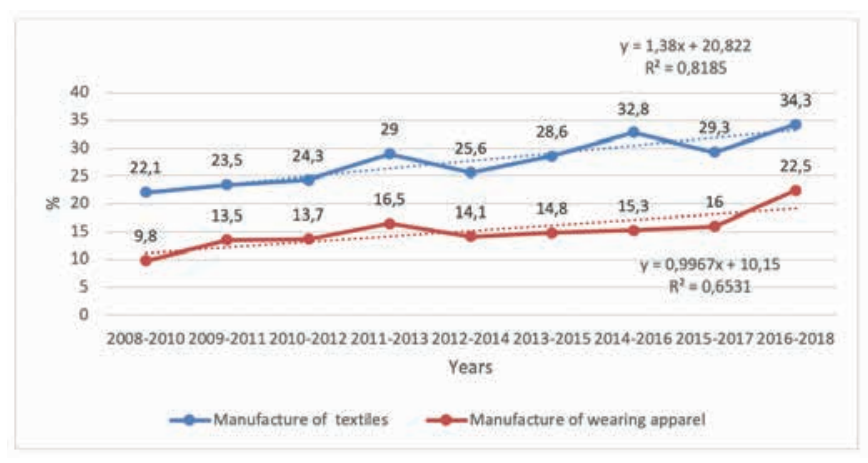

Figure 1. Enterprises that introduced new or improved products or business processes in the manufacture of textiles and wearing apparel in Poland during the period 2008-2018.

Source: Own calculations based on Central Statistical Office data from the Statistical Yearbook of Industry 2008-2019 [www.stat.gov.pl].

Table 1. Economic entities by ownership sectors, sections, and divisions in textile industry.

\begin{tabular}{|c|c|c|c|c|c|c|}
\hline \multirow{2}{*}{} & \multicolumn{2}{|c|}{ Total } & \multicolumn{2}{c|}{ Public sector } & \multicolumn{2}{c|}{ Private sector } \\
\cline { 2 - 7 } & $\mathbf{2 0 0 5}$ & $\mathbf{2 0 1 8}$ & $\mathbf{2 0 0 5}$ & $\mathbf{2 0 1 8}$ & $\mathbf{2 0 0 5}$ & $\mathbf{2 0 1 8}$ \\
\hline Manufacture of textiles & 3,506 & 5,915 & 16 & 3 & 3,490 & 5,912 \\
\hline Manufacture of wearing apparel & 20,336 & 13,174 & 16 & 4 & 20,320 & 13,170 \\
\hline
\end{tabular}

Source: Own calculations based on Central Statistical Office data from the Statistical Yearbook of Industry 2019 [www.stat.gov.pl]. 
Table 2. Basic data concerning the textile industry (2018).*

\begin{tabular}{|c|c|c|c|c|c|c|}
\hline Specification & $\begin{array}{c}\text { Economic } \\
\text { entities }\end{array}$ & $\begin{array}{c}\text { Sold } \\
\text { production, } \\
\text { in million } \\
\text { PLN }\end{array}$ & $\begin{array}{c}\text { Average paid } \\
\text { employment, } \\
\text { in thousand } \\
\text { PLN }\end{array}$ & $\begin{array}{c}\text { Labor } \\
\text { productivity, } \\
\text { in thousand } \\
\text { PLN }\end{array}$ & $\begin{array}{c}\text { Average } \\
\text { monthly } \\
\text { gross wages } \\
\text { and salaries, } \\
\text { in PLN }\end{array}$ & $\begin{array}{c}\text { Gross value } \\
\text { of fixed } \\
\text { assets, in } \\
\text { million PLN }\end{array}$ \\
\hline $\begin{array}{c}\text { Manufacture of } \\
\text { textiles }\end{array}$ & 196 & $10,779.1$ & 34.9 & 308.7 & $3,620.78$ & $6,234.9$ \\
\hline $\begin{array}{c}\text { Preparation and } \\
\text { spinning of textile } \\
\text { fibers }\end{array}$ & 12 & 834.4 & 2.2 & 385.8 & $3,697.58$ & 875.3 \\
\hline $\begin{array}{c}\text { Weaving of textiles } \\
\text { Finishing of textiles }\end{array}$ & 19 & 662.9 & 2.6 & 256.7 & $3,613.50$ & $3,496.89$ \\
\hline $\begin{array}{c}\text { Manufacture of other } \\
\text { textiles }\end{array}$ & 145 & $8,737.9$ & 27.1 & 322.3 & $3,629.35$ & $4,311.7$ \\
\hline $\begin{array}{c}\text { Manufacture of } \\
\text { wearing apparel }\end{array}$ & 296 & $4,178.0$ & 34.3 & 121.8 & $2,879.36$ & $1,888.5$ \\
\hline $\begin{array}{c}\text { of which manufacture } \\
\text { of wearing apparel, } \\
\text { except fur apparel }\end{array}$ & 262 & $3,370.3$ & 29.1 & 115.7 & $2,858.43$ \\
\hline
\end{tabular}

Note: *For entities with $>10$ employees.

Source: Own calculations based on Central Statistical Office data from the Statistical Yearbook of Industry 2019 [www.stat.gov.pl].

It is particularly visible in enterprises involved in the production of apparel, of which only $25.5 \%$ use social media.

Based on the analysis of the number of companies that introduced new or improved business products in the period 2008-2018 in Poland, the section of companies producing textiles and clothing is steadily increasing, as shown in Figure 1. On average, over the whole period studied, the number of companies that introduced new or improved business products among the textile companies increased by an average of 1.38 percentage points per year, while for apparel manufacturing companies, the average annual increase between 2008 and 2018 was almost 1 percentage point. In 2018, compared to 2008 , the number of companies that introduced new or improved business products among textile companies increased by $55 \%$ and among apparel manufacturing companies - by as much as $129.6 \%$.

\section{Global impact on the T\&A supply chain in Poland}

Globalization has led to profound structural changes in the global trade in T\&A [7]. They were based on trade liberalization and international agreements that directly changed the global supply chain [8]. The restructuring of the T\&A industry particularly affected the EU countries, such as Poland, which had to adapt the production profile to meet the market changes as well as technological and environmental conditions [9-11]. Even in highly industrialized countries such as the US, trade policies such as the North American Free Trade Agreement (NAFTA) do not solve the problem of the declining international competitiveness of the US textile industry, due to the high and constantly growing labor costs [12]. These changes took place with different intensities in all regions and countries, especially in the EU countries. In Poland, they resulted in the development of a network of business relations and cooperation with the German textile industry. Poland, Romania, and Tunisia have

Table 3. Product and business process innovative enterprises in textile industry by size and type in Poland during the period $2016-2018$.

\begin{tabular}{|c|c|c|c|c|c|c|c|}
\hline \multirow{2}{*}{ Specification } & \multicolumn{6}{|c|}{ Enterprises that introduced new or improved products or business processes during the } \\
period 2016-2018
\end{tabular}

Source: Own calculations based on Central Statistical Office data from the Statistical Yearbook of Industry 2019 [www.stat.gov.pl]. 
Table 4. Enterprises in the textile industry using selected information and communications technology approaches.

\begin{tabular}{|c|c|c|c|c|c|c|c|c|}
\hline \multirow[b]{2}{*}{ Specification } & \multirow[b]{2}{*}{ Computers } & \multicolumn{3}{|c|}{ Internet access } & \multirow[b]{2}{*}{$\begin{array}{c}\text { Own } \\
\text { website }\end{array}$} & \multirow[b]{2}{*}{ E-government } & \multirow{2}{*}{$\begin{array}{l}\text { Enterprises } \\
\text { buying } \\
\text { services } \\
\text { in cloud } \\
\text { computing }\end{array}$} & \multirow{2}{*}{$\begin{array}{c}\text { Enterprises } \\
\text { using social } \\
\text { media }\end{array}$} \\
\hline & & Total & Broadband & Mobile & & & & \\
\hline & \multicolumn{8}{|c|}{$\%$ of total enterprises of a given economic activity } \\
\hline $\begin{array}{c}\text { Manufacture } \\
\text { of textiles }\end{array}$ & 95.9 & 95.9 & 95.9 & 58.9 & 71.3 & 91.1 & 6.6 & 21.5 \\
\hline $\begin{array}{c}\text { Manufacture } \\
\text { of wearing } \\
\text { apparel }\end{array}$ & 86.4 & 86.4 & 86.4 & 39.0 & 51.8 & 89.9 & 5.5 & 25.5 \\
\hline
\end{tabular}

Source: Own calculations based on Central Statistical Office data from the Statistical Yearbook of Industry 2019 [www.stat.gov.pl].

played a key role in the subcontracting and outsourcing of production processes by Germany for many years [13]. It is worth emphasizing that the importance of technical textile production in Poland is strongly related to industrial customers and proves the effectiveness of the niche market strategy in the production of apparel $[14,15]$. The niche strategy is also used in the Portuguese T\&A industry, which is also strongly affected by globalization. However, it concerns the reorientation of production toward high-quality niches, such as Portuguese cotton flannel and some synthetic fabrics [16]. The production of clothing in the EU includes two categories: low- to mediumpriced products for the mass market, produced in countries such as Poland, Hungary, Romania, and Portugal; and highend luxury apparel, made by developed members of the EU such as Italy, France, and Germany. International agreements such as the Trans-Atlantic Trade and Investment Partnership (T-TIP) strengthen intraregional trade and constitute an opportunity for Poland in the production of apparel for the EU mass market [17].

These changes have led to the emergence of trade patterns and industrial development in the T\&A manufacturing sector depending on the income gap between countries [18]. Diversification of production in the textile industry is particularly visible in relation to its innovation. Poland, together with peripheral regions in Spain, Italy, the Baltic States, and some Eastern European countries, forms the group of regions with the lowest patent intensities in the EU [19]. In 2018, the number of national patent applications for the textile industry was 29 (including the paper industry) [Statistical Yearbook of Industry; Central Statistical Office 2019]. The opening of the EU textile industry to products from China and the consequences resulting from that fact are also worth noting. Research carried out in Spain confirms the negative impact of introducing Chinese products into the EU market on the technical efficiency in the textile industry in the EU countries [20]. China, which is one of the largest producers of T\&A, is shifting its production from the mid-range and low-end products to higher-quality and upstream goods [21]. This has a negative impact on the competitiveness of T\&A production in Poland, especially in the absence of global luxury brands [22]. In terms of international flows of the products of the T\&A industry, differences in technical efficiency are visible in the import of raw materials into Poland. They have a direct effect, for instance, on the scale of import of raw materials into Poland from Bangladesh [23].
The T\&A supply chain includes raw materials, spinning, weaving/knitting, and dyeing/finishing, as well as the producer and the brand/customer. Their efficiency depends primarily on the supply chain processes. Research from the Egyptian textile industry shows that the planning-and-delivery process has the greatest impact on the overall performance of the supply chain. Sourcing and manufacturing affect the process to a lesser extent [24]. At the same time, the T\&A supply chain, due to the overwhelming share of small- and medium-sized enterprises, faces a problem in terms of inclusion and participation of these enterprises in global value chains [25]. This issue also applies to small- and medium-sized enterprises operating in the T\&A sector in Poland, as they encounter real limitations in co-creating the global supply chain. The problem refers to system integration and limitations in sharing production and sales data with other supply chain participants [26]. The key issue for Polish enterprises in the context of global expansion in the competitive T\&A market is the development of a firmspecific strategy, as shown by the example of companies such as Zara and Uniqlo [27].

A large number of textile companies are outsourcing a variety of operations to developing countries, such as India, African countries, China, and Brazil, to reduce costs and avoid restrictive environmental and labor laws [28]. Therefore, questions about the effectiveness of actions taken by enterprises in the supply chain are perfectly legitimate. When outsourcing services, it is extremely important to control and evaluate textiles in the supply chain. It should cover all types of inspections and assessments during the entire textile production process, primarily, quality control, along with the assessment of the properties of textiles and the identification of errors that occur in each link of the supply chain [29]. The main aim is to ensure that the quality of the finished textile products is at the customers' expectation level [30]. Managing the production of textile products in an effective supply chain refers to planning, organizing, monitoring, and controlling production activities such as line balancing and layout of production halls, as well as overall information flow management [31]. Supply chain management in the textile industry, while requiring the coordination of both information flow and customer relations activities, is certainly profitable but poses various challenges in terms of effective management [32]. Existing research on supply chain management in the T\&A industry focuses on three core processes, namely, sourcing, production, and retailing (Table 5). It is conducted at two levels: industry; and supply- 
Table 5. Research on textile and apparel supply chain management in the business field.

\begin{tabular}{|c|c|c|c|}
\hline $\begin{array}{l}\text { Covered } \\
\text { topic }\end{array}$ & Description & Research scope & Source \\
\hline \multicolumn{4}{|c|}{ Sourcing of raw material } \\
\hline & $\begin{array}{l}\text { Methodological framework to characterize the geographical configuration } \\
\text { of a firm's supplier and retailer networks }\end{array}$ & $\begin{array}{l}\text { Adidas, Benetton, } \\
\text { C\&A, and Puma }\end{array}$ & [33] \\
\hline & $\begin{array}{l}\text { Examination of multisourcing triads in terms of coordination, } \\
\text { collaboration, and integration }\end{array}$ & $\begin{array}{l}103 \text { suppliers in the } \\
\text { textiles-and-apparel } \\
\text { industry }\end{array}$ & [34] \\
\hline & $\begin{array}{l}\text { Assessment of Haiti vs China as apparel-sourcing partners through } \\
\text { evaluation of macro-, supply-chain-, and microlevel environments }\end{array}$ & 41 apparel companies & [35] \\
\hline & Examination of the trade-offs in sourcing and sales strategies & Apparel industry & [36] \\
\hline \multicolumn{4}{|c|}{ Manufacturing } \\
\hline & $\begin{array}{c}\text { Identification of the essential steps in fashion product development } \\
\text { processes, which include planning, product designing, manufacturing, } \\
\text { and product launching }\end{array}$ & Apparel industry & [37] \\
\hline & $\begin{array}{l}\text { Conceptualization of sustainable supply chain management (SSCM) to } \\
\text { delineate mechanisms that facilitate the implementation of supply chain } \\
\text { sustainability }\end{array}$ & $\begin{array}{l}156 \text { apparel } \\
\text { manufacturers }\end{array}$ & [38] \\
\hline & $\begin{array}{l}\text { Identification and prioritization of the success factors and challenges } \\
\text { related to competitive manufacturing capabilities in a high-cost } \\
\text { environment; identification of their potential to support future reshoring in } \\
\text { textile and clothing (T\&C) supply chains }\end{array}$ & $\begin{array}{l}\text { Swedish textile and } \\
\text { clothing industry }\end{array}$ & [39] \\
\hline \multicolumn{4}{|c|}{ Retailing } \\
\hline & $\begin{array}{l}\text { Exploration of the drivers and barriers to omnichannel retailing in China, } \\
\text { and attempts to understand how companies formulate their business } \\
\text { strategies during their transformation to omnichannel retailing }\end{array}$ & $\begin{array}{l}\text { Factories and } \\
\text { distribution centers }\end{array}$ & [40] \\
\hline & $\begin{array}{l}\text { Definition of C\&T as the science of investigating the satisfaction } \\
\text { processes of human clothing needs and wants }\end{array}$ & Conceptual paper & [41] \\
\hline & $\begin{array}{l}\text { Project to balance the design, schedule, and cost of the production and } \\
\text { logistics for a major apparel manufacturer }\end{array}$ & $\begin{array}{l}\text { Major apparel } \\
\text { manufacturer }\end{array}$ & [42] \\
\hline
\end{tabular}

chain actors, such as raw material suppliers, producers, and retailers. This allows understanding the specific relationships and principles of creating supply chains that are focused on customer expectations for products considering both the changes in fashion and sustainability. It should be stressed that while many studies are aimed at clarifying local and national supply chain management problems, they are considered from the perspective of global dependencies between the raw material base and the sales networks.

\section{Changes in production and trade in the T\&A industry in Poland}

The value of the total production sold in Poland, as well as textiles and apparel, in the period 2010-2018 systematically grew both in nominal and real terms. The value of total production of goods sold in Poland in 2018, compared to 2010, increased by as much as $50.86 \%$, while simultaneously, the value of sold production of textiles and apparel increased by $44.3 \%$. The share of the value of the production of textiles and apparel sold in the value of the total production of goods sold in Poland in the period $2010-2018$ ranges from $1.1 \%$ to $1.19 \%$ (Table 6).

It is worth noting that the increase in the value of the sold production of textiles and apparel in the analyzed period stemmed mainly from the increase in the value of the sold production of textiles by $63.16 \%$ because the increase in the

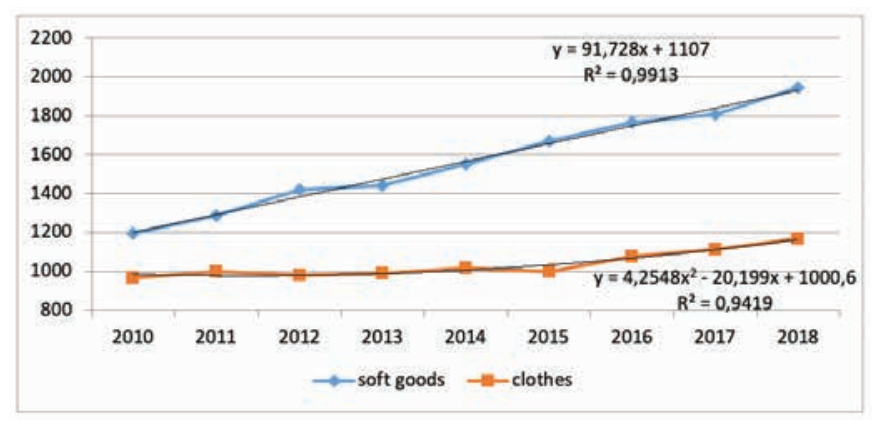

Figure 2. Value of the sold production of textiles and apparel in the period 2010-2018 in Poland.

Source: Own calculations based on Central Statistical Office data from the Statistical Yearbook of Industry 2019 [www.stat.gov.pl]. 
Table 6. Value of total production sold, as well as textiles and apparel, in the period 2010-2018 in Poland in nominal and real terms. *

\begin{tabular}{|c|c|c|c|c|c|}
\hline Years & $\begin{array}{l}\text { Total value of sold } \\
\text { production of } \\
\text { goods in Poland } \\
\text { at current prices, } \\
\text { in thousand euros }\end{array}$ & $\begin{array}{l}\text { Total value of sold } \\
\text { production of } \\
\text { goods in Poland } \\
\text { in constant prices } \\
(2010=100) \text {, in } \\
\text { thousand euros }\end{array}$ & $\begin{array}{l}\text { Total value of } \\
\text { sold production } \\
\text { of textiles and } \\
\text { apparel in Poland } \\
\text { at current prices, } \\
\text { in thousand euros }\end{array}$ & $\begin{array}{l}\text { Value of the } \\
\text { total production } \\
\text { of textiles and } \\
\text { apparel sold } \\
\text { in Poland in } \\
\text { constant prices } \\
(2010=100)\end{array}$ & $\begin{array}{c}\text { Share in } \\
\text { percentage of } \\
\text { total value, in \% }\end{array}$ \\
\hline 2010 & $181,350,995.6$ & $181,350,995.6$ & $2,158,749.0$ & $2,167,418.7$ & 1.19 \\
\hline 2011 & $208,034,394.1$ & $193,340,514.9$ & $2,287,079.0$ & $2,211,875.2$ & 1.10 \\
\hline 2012 & $216,051,145.6$ & $194,376,599.8$ & $2,402,559.0$ & $2,266,885.9$ & 1.11 \\
\hline 2013 & $219,517,191.5$ & $200,096,177.5$ & $2,432,426.3$ & $2,315,909.8$ & 1.11 \\
\hline 2014 & $223,479,783.7$ & $206,810,348.4$ & $2,570,704.5$ & $2,467,302.7$ & 1.15 \\
\hline 2015 & $228,437,710.7$ & $216,153,846.6$ & $2,668,673.0$ & $2,551,126.1$ & 1.17 \\
\hline 2016 & $238,097,343.7$ & $225,519,568.1$ & $2,843,723.1$ & $2,691,550.3$ & 1.19 \\
\hline 2017 & $259,099,138.1$ & $238,495,546.9$ & $2,920,185.5$ & $2,797,490.9$ & 1.13 \\
\hline 2018 & $273,583,160.6$ & $246,648,186.5$ & $3,115,425.2$ & $2,946,226.5$ & 1.14 \\
\hline $\begin{array}{c}\text { Year } \\
2010=100\end{array}$ & 150.86 & 136.00 & 144.31 & 135.93 & 95.80 \\
\hline $\begin{array}{l}\text { Previous } \\
\text { year=100 }\end{array}$ & 105.59 & 103.42 & 102.53 & 105.32 & 100.88 \\
\hline
\end{tabular}

Note: *The euro exchange rate as on December 12, 2019, i.e., the update of data on the value of production sold in Poland (1 euro = PLN 4.2851); https://www.nbp.pl/home.aspx?navid=archa\&c=/ascx/tabarch.ascx\&n=a240z191212.

Source: Own calculations based on Central Statistical Office data from the Statistical Yearbook of Industry 2019 [www.stat.gov.pl].

value of production of apparel sold at that time amounted only to $21.04 \%$ (Figure 2).

A particularly high increase in the value of textiles sold, by approximately $70 \%$, was recorded for yarns and threads and other textile products, including two groups of products, i.e., carpets, rugs and other textile floor coverings; and nonwovens and goods made of nonwovens, which almost doubled the value of production in the analyzed period. Only the value of the production sold of fabrics showed a drop in the value of production sold by $3.1 \%$ in the compared years (Table 7 ).

On the other hand, the analysis of the value of production of apparel sold shows that in the analyzed years, the value of protective and work apparel produced in Poland increased by as much as $115 \%$, where the strongest increase (by $27.2 \%$ ) in the value of production of this apparel was recorded in 2018 compared to the previous one. In 2018 , compared to 2010 , only the value of the production of leather apparel sold decreased by $10.2 \%$ (Table 8 ). This confirms the earlier forecasts about the decreasing importance of the production of the leather industry in Poland [43].

The domestic T\&A market is highly dependent on the relationship between imports and exports. In the years 20042020 , there was a constant lead of imports over exports of T\&A products (Figure 3 ), with a systematic increase in the value of imports and exports. The share of the import value of T\&A products in the total import value in 2019 amounted to $5.12 \%$ and, compared to 2004 , decreased by $0.52 \%$. During this period, export decreased by $0.97 \%$ and, in 2019 , amounted to $3.92 \%$ of the total value of exports.

The largest import of T\&A products to Poland in 2019 came from countries such as China, Germany, Bangladesh, and Turkey. On the other hand, export from Poland was directed to Germany, the Czech Republic, Romania, and Ukraine (Figure 4). Poland's largest trade in T\&A products is with Germany, which is influenced by the proximity of both markets and the deepening integration of the Polish and German economies. It is affected by differences in labor costs. This also applies to extended cooperation and integration of the T\&A supply chain. Based on the sections for "Textiles and textile articles" (Figure 5), the analysis of the export and import structure of T\&A products in 2019 showed that three sections have the largest share in the structure of exports and imports: 62 (Articles of apparel and

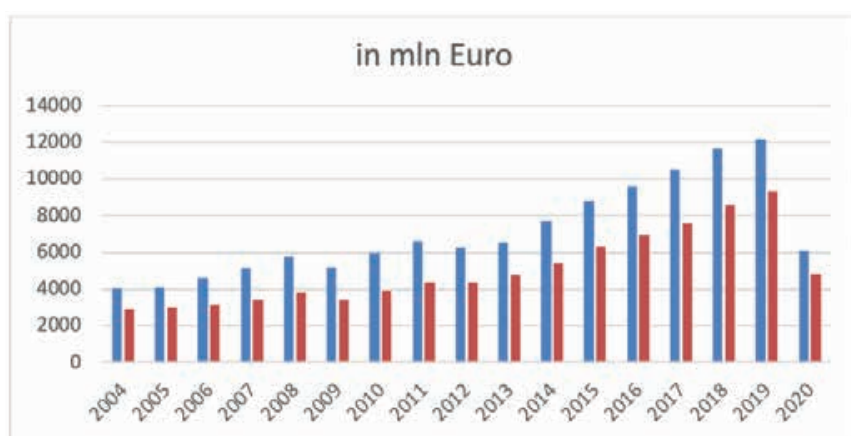

Figure 3. Exports and imports in Poland (2004-2020). Source: Own calculations based on data from the Foreign Trade database of the Central Statistical Office. 
Table 7. Value of the sold production of textile products in Poland in the period 2010-2018 (in thousand euros).

\begin{tabular}{|c|c|c|c|c|c|}
\hline \multirow[b]{3}{*}{ Years } & \multicolumn{5}{|c|}{ Value of total textile products sold in Poland at current prices, in thousand euros } \\
\hline & \multirow[b]{2}{*}{ Yarn and threads } & \multirow[b]{2}{*}{ Fabrics } & \multirow[b]{2}{*}{ Other textiles } & \multicolumn{2}{|c|}{ Other textile products } \\
\hline & & & & $\begin{array}{l}\text { Carpets, rugs, } \\
\text { and other textile } \\
\text { floor coverings }\end{array}$ & $\begin{array}{l}\text { Nonwovens and } \\
\text { goods made } \\
\text { from nonwovens, } \\
\text { except apparel }\end{array}$ \\
\hline 2010 & $113,155.2$ & $141,062.1$ & $938,726.7$ & $70,601.0$ & $105,308.5$ \\
\hline 2011 & $144,239.8$ & $129,252.6$ & $1,013,546.0$ & $91,158.6$ & $124,218.9$ \\
\hline 2012 & $154,844.4$ & $128,630.0$ & $1,137,629.5$ & $103,006.4$ & $131,625.8$ \\
\hline 2013 & $140,526.3$ & $135,254.3$ & $1,166,172.2$ & $112,598.8$ & $142,305.9$ \\
\hline 2014 & $159,243.7$ & $146,491.8$ & $1,248,034.8$ & $122,846.0$ & $165,432.3$ \\
\hline 2015 & $170,579.0$ & $141,030.0$ & $1,357,591.3$ & $133,319.5$ & $180,203.1$ \\
\hline 2016 & $185,366.8$ & $152,143.3$ & $1,431,257.9$ & $136,027.2$ & $192,000.2$ \\
\hline 2017 & $184,666.2$ & $130,770.0$ & $1,494,020.9$ & $137,193.5$ & $200,732.1$ \\
\hline 2018 & $197,731.8$ & $136,704.1$ & $1,611,969.3$ & $136,875.3$ & $209,549.1$ \\
\hline Year 2010=100 & 174.7 & 96.9 & 171.7 & 193.9 & 199.0 \\
\hline $\begin{array}{l}\text { Previous } \\
\text { year=100 }\end{array}$ & 107.1 & 104.5 & 107.9 & 99.8 & 104.4 \\
\hline
\end{tabular}

Source: Own calculations based on Central Statistical Office data from the Statistical Yearbook of Industry 2019 [www.stat.gov.pl].

Table 8. The value of production of clothes sold in Poland in the period 2010-2018 (in thousand euros).

\begin{tabular}{|c|c|c|c|c|c|}
\hline \multirow{2}{*}{ Years } & \multicolumn{5}{|c|}{ Value of production of clothes sold in Poland at current prices, in thousand euros } \\
\hline & Leather apparel & $\begin{array}{l}\text { Workwear and } \\
\text { protective wear }\end{array}$ & Other outerwear & Underwear & $\begin{array}{l}\text { Other apparel } \\
\text { and clothing } \\
\text { accessories }\end{array}$ \\
\hline 2010 & $5,488.1$ & $101,768.5$ & $365,381.4$ & $158,589.9$ & $124,716.8$ \\
\hline 2011 & $3,788.1$ & $110,816.8$ & $364,588.5$ & $160,963.0$ & $133,000.4$ \\
\hline 2012 & $4,704.4$ & $123,597.6$ & $342,440.5$ & $167,038.7$ & $140,201.6$ \\
\hline 2013 & $5,643.8$ & $149,754.1$ & $338,136.1$ & $165,838.0$ & $134,813.9$ \\
\hline 2014 & $4,662.8$ & $150,210.6$ & $350,186.9$ & $171,091.4$ & $139,749.6$ \\
\hline 2015 & $4,456.4$ & $155,324.8$ & $365,139.8$ & $167,454.3$ & $118,570.9$ \\
\hline 2016 & $4,422.3$ & $153,457.0$ & $389,748.0$ & $195,254.4$ & $140,565.7$ \\
\hline 2017 & $4,188.8$ & $172,463.5$ & $374,261.5$ & $214,531.7$ & $150,206.9$ \\
\hline 2018 & $4,926.6$ & $219,316.3$ & $399,010.2$ & $218,472.0$ & $148,780.0$ \\
\hline Year $2010=100$ & 89.8 & 215.5 & 109.2 & 137.8 & 119.3 \\
\hline $\begin{array}{c}\text { Previous } \\
\text { year }=100\end{array}$ & 117.6 & 127.2 & 106.6 & 101.8 & 99.1 \\
\hline
\end{tabular}

Source: Own calculations based on Central Statistical Office data from the Statistical Yearbook of Industry 2019 [www.stat.gov.pl].

clothing accessories, not knitted or crocheted), 61 (Articles of apparel and clothing accessories, knitted or crocheted), and 63 (Other made-up textile articles; worn clothing and worn textile articles; rags). Their total share in total exports amounted to $80.7 \%$, and the share in total imports was $70.3 \%$. 


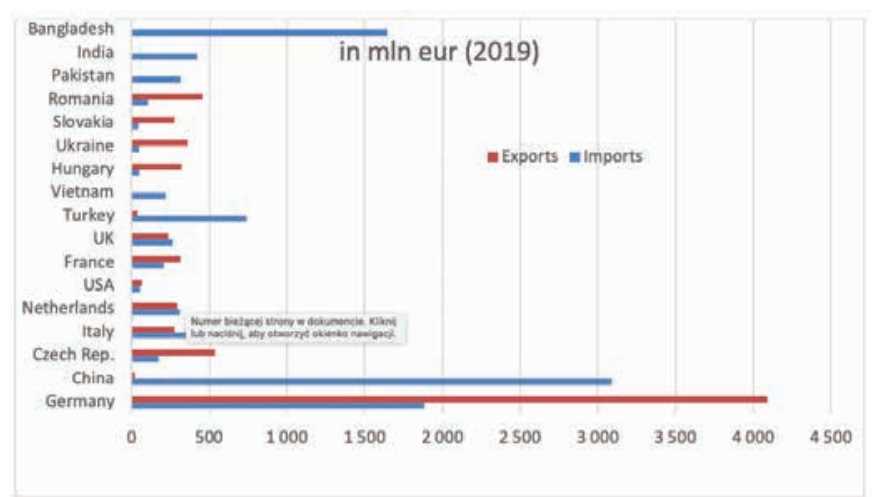

Figure 4. Exports and imports of textiles and textile articles (2019). Source: Own calculations based on data from the Foreign Trade database of the Central Statistical Office.

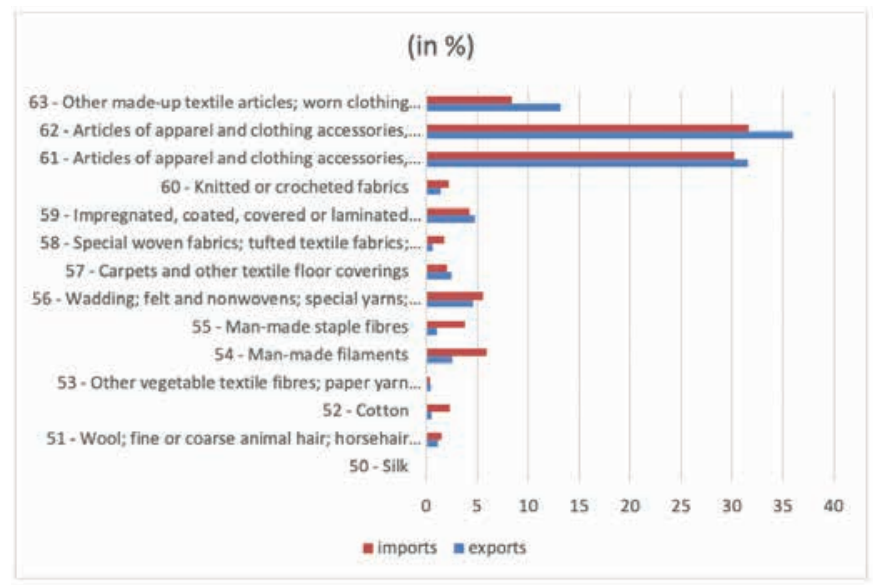

Figure 5. Structure of exports and imports of textiles and textile articles (2019). Source: Own calculations based on data from the Foreign Trade database of the Central Statistical Office.

\section{Conclusion}

The research shows that the T\&A industry production in Poland, similarly to that in other EU countries, is based on small companies. However, the number of small companies in Poland is several percentages lower than the EU average. The research revealed very low innovation in the production of T\&A products, which is influenced by the fact that the industry is classified as a low-technology industry. In addition, final products dominate in the import structure, which indirectly inhibits the development of product innovation at the level of searching for new solutions in the field of material engineering and innovative materials for the T\&A industry. Innovation is also not favored by the existing model of cooperation with Germany based on outsourcing production to Polish companies. The study demonstrated that the increase in the value of the sold production of the T\&A industry in Poland related mainly to textile products and, to a lesser extent, apparel. The production of workwear is an exception, which indicates the progressive specialization of the industry and the development of strategies based on filling market niches. The supply chain of the T\&A industry in Poland, as in other EU countries, adapts to the changing preferences of customers. The key to its development from the perspective of supply chain management is the supply chain planning and quick reaction to changes occurring on the global market, with particular emphasis on the German market. We may conclude that the supply chain of the T\&A industry in Poland, as in other EU countries, is an accepted concept limited by different trade factors within the EU. Examples of import and export cases discussed in the paper provide valuable indicators for how theoretical concepts of supply chain can be successfully applied in practice. However, this study has also shown that the studied supply chain is experiencing uncertainty and facing the challenge of removing trade boundaries in textile industries among European countries. This research is an example of a cross-disciplinary analysis that becomes increasingly applicable to the dynamic and integrated supply chains in the European T\&A industry. It provides important insights for researchers seeking solutions for import- and export-related problems of supply chains.

\section{References}

[1] Jabłońska, M., Stawska, J., Czechowska, D. I. (2020). County-specific determinants of textile industry development in Poland: Comparative analysis of the Years 2007 and 2017. Autex Resarch Journal, 20(2), 186-193. doi: 10.2478/aut-2019-0064.

[2] Department of Strategy and International Analysis. (2017). Apparel industry: Increasing importance of polish exporters in the world. Retrieved from https://wspieramyeksport.pl/ api/public/files/1068/PKO_BRANZA_ODZIEZOWA.pdf

[3] Amed, I., Berg, A., Brantberg, L., Hedrich, S. (2020). The state of fashion, McKinsey. Colourage, 63(12), 42-43.

[4] Euratex (2020). Facts \& Key Figures of the European Textile and Clothing Industry.

[5] Dezi, L., Del Giudice, M. (2014). Economic performance and capital structure choices: A nonparametric analysis of the southern Italian textile-clothing industry. International Studies of Management and Organization, 44(1), 42-54. doi: 10.2753/IMO0020-8825440103.

[6] Molina-Morales, F. X., Expósito-Langa, M. (2012). The impact of cluster connectedness on firm innovation: $R \& D$ effort and outcomes in the textile industry. Entrepreneurship and Regional Development, 24(7-8), 685-704. doi: 10.1080/08985626.2012.710260.

[7] Lim, M. (2003). The development pattern of the global textile industry and trade: Part I: Evidence from textile exports of the ec, the far east, and emerging textile exporting countries in the 1980s. Journal of the Textile Institute, 94(1-2), 32-52. doi: 10.1080/00405000308630618.

[8] Chester, K. M., To, Z.M, Z., Chun-sun, L., Jimmy M.T, C., K.L, M. (2005). Trade liberalization in the post-MFA regime: The influences of CEPA and quota phasing-out on Hong Kong's Textiles and Clothing Manufacturing Industry. Research Journal of Textile and Apparel, 9(4), 70-76. doi: 10.1108/RJTA-09-04-2005-B007.

[9] Keenan, M., Saritas, O., Kroener, I. (2004). A dying industry - or not? The future of the European textiles and clothing industry. Foresight, 6(5), 313-322. doi: 10.1108/14636680410563016.

[10] Ostrowska, E., Lu, S., Kowalewska, M., Jachuła, M., Huml, I., et al. (2012). Is technological change really skillbiased? Evidence from the introduction of ICT on the Italian textile industry (1980-2000). Journal of Fashion Marketing and Management, 11(1), 2842-2854. doi: 10.1108/13612020710734427. 
[11] Baccini, A., Cioni, M. (2010). Is technological change really skill-biased? Evidence from the introduction of ICT on the Italian textile industry (1980-2000). New Technology, Work and Employment, 25(1), 80-93. doi: 10.1111/j.1468005X.2009.00240.x.

[12] Lim, M., Suh, M. W., Gaskill, L. (2009). Economic analysis of US textile production activities under the North American Free Trade Agreement. Journal of the Textile Institute, 100(7), 612-625. doi: 10.1080/00405000802125170.

[13] Kooli, K., Wright, L. T., Wright, A. (2010). Business implications in the subcontracting alliance life cycle: Case examples from the Tunisian clothing and textile industries. Journal of Business and Industrial Marketing, 25(5), 372382. doi: 10.1108/08858621011058133.

[14] Adler, U. (2004). Structural change: The dominant feature in the economic development of the German textile and clothing industries. Journal of Fashion Marketing and Management, 8(3), 300-319. doi: 10.1108/13612020410547815.

[15] Parrish, E. D., Cassill, N. L., Oxenham, W. (2006). Niche market strategy in the textile and apparel industry. Journal of Fashion Marketing and Management, 10(4), 420-432. doi: 10.1108/13612020610701956.

[16] Truett, L. J., Truett, D. B. (2019). Challenges in the Portuguese textile and clothing industry: A fight for survival. Applied Economics, 51(26), 2842-2854. doi: 10.1080/00036846.2018.1558362.

[17] Lu, S. (2018). Trans-Atlantic Trade and Investment Partnership: an opportunity or a threat to the EU textile and apparel industry? Journal of the Textile Institute, 109(7), 933-941. doi: 10.1080/00405000.2017.1388345.

[18] Kilduff, P., Chi, T. (2007). Analysis of comparative advantage in the textile complex: A study of Eastern European and former Soviet Union nations. Journal of Fashion Marketing and Management, 11(1), 82-105. doi: 10.1108/13612020710734427.

[19] Giannini, V., lacobucci, D., Perugini, F. (2019). Local variety and innovation performance in the EU textile and clothing industry. Economics of Innovation and New Technology, 28(8), 841-857. doi: 10.1080/10438599.2019.1571668.

[20] De Jorge-Moreno, J., Carrasco, O. R. (2015). Technical efficiency and its determinants factors in Spanish textiles industry (2002-2009). Journal of Economic Studies, 42(3), 346-357. doi: 10.1108/JES-06-2013-0085.

[21] Wu, H. L., Chen, C. H., Chen, L. T. (2012). Determinants of Foreign Trade in China's Textile Industry. International Trade Journal, 26(2), 112-138. doi: 10.1080/08853908.2012.657586.

[22] Arienti, P., Casale, M., Lee, V., Scaramuzzi, V., Sahu, P., et al. (2019). Global powers of luxury goods 2019: Bridging the gap between the old and the new. Deloitte Touche Tohmatsu Limited., 1-46. Retrieved from https:// www2.deloitte.com/content/dam/Deloitte/ch/Documents/ consumer-business/deloitte-en-cip-global-powers-ofluxury-goods-2019-report.pdf.

[23] Jaforullah, M. (1999). Production technology, elasticity of substitution and technical efficiency of the handloom textile industry of Bangladesh. Applied Economics, 31(4), 437-442. doi: 10.1080/000368499324147.
[24] Abdelsalam, H. M., Fahmy, G. A. (2009). Major variables affecting the performance of the textile and clothing supply chain operations in Egypt. International Journal of Logistics Research and Applications, 12(3), 147-163. doi: 10.1080/13675560902729334.

[25] Chen, C. L. (2019). Value creation by SMEs participating in global value chains under industry 4.0 trend: Case Study of Textile Industry in Taiwan. Journal of Global Information Technology Management, 22(2), 120-145. doi: 10.1080/1097198X.2019.1603512.

[26] Kuo, T. C., Hsu, C. W., Huang, S. H., Gong, D. C. (2014). Data sharing: A collaborative model for a green textile/clothing supply chain. International Journal of Computer Integrated Manufacturing, 27(3), 266-280. doi: 10.1080/0951192X.2013.814157.

[27] Anwar, S. T. (2017). Zara vs. Uniqlo: Leadership strategies in the competitive textile and apparel industry. Global Business and Organizational Excellence, 36(5), 26-35. doi: 10.1002/joe.21805.

[28] Guarnieri, P., Trojan, F. (2019). Decision making on supplier selection based on social, ethical, and environmental criteria: A study in the textile industry. Resources, Conservation and Recycling, 141, 347-361.

[29] Â, Y. L., Wang, Y., Yu, C. (2010). Int. J. production economics investigating the drivers of the innovation in channel integration and supply chain performance: A strategy orientated perspective. Intern. Journal of Production Economics, 127(2), 320-332. doi: 10.1016/j. ijpe.2009.08.009.

[30] Djokaj, A., Vatin, N. (2015). Logistics in the Function of Customer Service - Relevance for the Engineering Management, 117, 802-807. doi: 10.1016/j. proeng.2015.08.255.

[31] Ngai, E. W. T., Peng, S., Alexander, P., Moon, K. K. L. (2014). Decision support and intelligent systems in the textile and apparel supply chain: An academic review of research articles. Expert Systems with Applications, 41(1), 81-91.

[32] Marsillac, E., Johnson, E. (2010). Global supply chain adaptations to improve financial performance Supply base establishment and logistics integration, 22(2), 204-222. doi: 10.1108/17410381111102225.

[33] Kalchschmidt, M., Birolini, S., Cattaneo, M., Malighetti, P., Paleari, S. (2020). The geography of suppliers and retailers. Journal of Purchasing and Supply Management, 26(4), 100626. doi: 10.1016/j.pursup.2020.100626.

[34] Vlachos, I., Dyra, S. C. (2020). Theorizing coordination, collaboration and integration in multi-sourcing triads (B3B triads). Supply Chain Management, 25(3), 285-300. doi: 10.1108/SCM-01-2019-0006.

[35] Uluskan, M., Godfrey, A. B. (2018). Business environmentsupply chain framework and benchmarking supply chain structures: Haiti versus China. Benchmarking, 25(8), 3021-3044. doi: 10.1108/B/J-11-2017-0293.

[36] Phadnis, S. S., Fine, C. H. (2017). End-to-end supply chain strategies: A parametric study of the apparel industry. Production and Operations Management, 26(12), 23052322. doi: 10.1111/poms. 12779.

[37] Fung, Y.-N., Chan, H.-L., Choi, T.-M., Liu, R. (2021). Sustainable product development processes in fashion: Supply chains structures and classifications. International Journal of Production Economics, 231. doi: 10.1016/j. ijpe.2020.107911. 
[38] Roy, V., Silvestre, B. S., Singh, S. (2020). Reactive and proactive pathways to sustainable apparel supply chains: Manufacturer's perspective on stakeholder salience and organizational learning toward responsible management. International Journal of Production Economics, 227. doi: 10.1016/j.ijpe.2020.107672.

[39] Pal, R., Harper, S., Vellesalu, A. (2018). Competitive manufacturing for reshoring textile and clothing supply chains to high-cost environment: A Delphi study. International Journal of Logistics Management, 29(4), 1147-1170. doi: 10.1108/IJLM-10-2017-0270.

[40] Ye, Y., Lau, K. H., Teo, L. K. Y. (2018). Drivers and barriers of omni-channel retailing in China: $A$ case study of the fashion and apparel industry. International Journal of Retail and Distribution Management, 46(7), 657-689. doi: 10.1108/IJRDM-04-2017-0062.
[41] Ha-Brookshire, J. E., Hawley, J. M. (2013). Envisioning the Clothing and Textile-Related Discipline for the 21st Century Its Scientific Nature and Domain From the Global Supply Chain Perspective. Clothing and Textiles Research Journal, 31(1), 17-31. doi: 10.1177/0887302 x12470024.

[42] Dai, H., Tseng, M. M. (2011). Determination of production lot size and DC location in manufacturer-DC-retailer supply chains. International Journal of Logistics Systems and Management, 8(3), 284-297. doi: 10.1504/ IJLSM.2011.038988.

[43] Biadała, A., Sadowski, A., Więcek, J. (2009). Prognozy rozwoju przemysłu skórzanego na tle innych sektorów gospodarki. Przegląd Włókienniczy-Włókno, Odzież, Skóra, 39-42. 